\title{
Giant Cell Tumor of the Larynx: A Clinicopathologic Series of Eight Cases and a Review of the Literature
}

\author{
Jacqueline A. Wieneke, M.D., Francis H. Gannon, M.D., Dennis K. Heffner, M.D., \\ Lester D. R. Thompson, M.D. \\ Department of Endocrine and Otorhinolaryngic - Head \& Neck Pathology (JAW, DKH, LDRT), and \\ Department of Orthopedic Pathology (FHG), Armed Forces Institute of Pathology, Washington, DC
}

True giant cell tumors of the larynx (GCTL) are quite rare, and only individual case reports are documented in the literature. Eight cases of GCTL were identified in the Otorhinolaryngic Pathology Tumor Registry between 1966 and 2000. There were 2 women and 6 men, ages 26 to 62 years (mean, 44.5 yrs). Patients presented with a palpable neck mass $(n=5)$, airway obstruction $(n=3)$, hoarseness $(n=$ $3)$, and dysphagia $(n=2)$. All tumors involved the thyroid cartilage, a few with local extension. The mean tumor size was $4.1 \mathrm{~cm}$. Histologically, the tumors showed no connection to the surface epithelium and arose in sites of ossification. The tumors had an expansile, infiltrative growth and consisted of numerous multinucleated osteoclast-like giant cells within a cellular stroma composed of plump, oval mononuclear cells. Of interest was that the nuclei of the giant cells were similar to the nuclei of the stromal cells. Treatment included biopsy only with adjuvant therapy $(n=2)$, local resection ( $n=$ $3)$, and total laryngectomy $(n=3)$. Follow-up showed 5 patients were alive without evidence of disease (mean follow-up, $6.9 \mathrm{yrs}$ ); 2 died of unrelated causes (mean survival, 22.2 yrs). No patients developed recurrences. GCTL are rare tumors that can cause significant airway obstruction. Complete surgical resection yields an excellent outcome without adjuvant therapy.

Copyright (C) 2001 by The United States and Canadian Academy of Pathology, Inc.

VOL. 14, NO. 12, P. 1209, 2001 Printed in the U.S.A

Date of acceptance: August 8, 2001.

Presented at the 90th Annual Meeting of the United States and Canadian Academy of Pathology, March 3-March 9, 2001, Atlanta, Georgia.

The opinions or assertions contained herein are the private views of the authors and are not to be construed as official or as reflecting the views of the Department of Defense.

Address reprint requests to: Jacqueline A. Wieneke, M.D., Department of Endocrine and Otorhinolaryngic-Head \& Neck Pathology, Building 54, Room G066-10, Armed Forces Institute of Pathology, 6825 16th Street, NW, Washington, DC 20306-6000; e-mail: wienekej@afip.osd.mil; fax: 202-782-3130.
KEY WORDS: Giant cell tumor, Histopathology, Larynx, Prognosis, Treatment.

Mod Pathol 2001;14(12):1209-1215

Primary giant cell tumors (GCTs) of the larynx (GCTL) are exceedingly rare, with only 20 well documented, histologically confirmed case reports in the literature (Table $1 ; 1-20)$. Nonepithelial tumors of the supporting structures (cartilages) of the larynx are uncommon and account for less than $2 \%$ of all primary laryngeal neoplasms (21-25). Although there are many comprehensive studies of GCTs of bone (26, 27), which are low-grade neoplasms usually affecting the long bones of the skeletal system, generally occurring in women in the 3rd decade of life and demonstrating a potential for local recurrence and occasionally for "metastasis," there is no single comprehensive clinicopathologic evaluation of GCTL (to our knowledge and according to MEDLINE, searched from 1966-2000). A number of tumors of the larynx contain giant cells, including spindle cell (sarcomatoid) carcinoma, osteosarcoma, chondrosarcoma, chondroma, aneurysmal bone cyst, infectious disorders, teflonomas, and rheumatoid nodules. A separation of these lesions from GCT is important, especially in light of the striking differences in patient management. Therefore, it is the intention of this study to provide an analysis of GCTL encompassing the use of clinical features, radiographic features, histologic findings, and follow-up information applied to a group of 8 patients with GCTL, and then to compare these results with those reported in the literature.

\section{METHODS}

The records of eight patients with tumors diagnosed as "giant cell tumor" were identified in the files of the Otorhinolaryngic - Head \& Neck Registry of the Armed Forces Institute of Pathology from 1966 to 2000. The eight patients represented $0.09 \%$ of the 8995 patients with benign and malignant primary laryngeal neoplasms who were seen in consultation during this same time period. All eight 
TABLE 1. Literature Summary of all 20 Case Reports of GCTL (1-20)

\begin{tabular}{ll}
\hline \multicolumn{1}{c}{ Variable } & Parameter \\
\hline Gender & 19 \\
Males & 1 \\
Females & \\
Age at presentation (y) & $23-60$ \\
Range & 40.2 \\
Average & \\
Location & 12 \\
Thyroid cartilage & 4 \\
Cricoid cartilage & 1 \\
Cricothyroid cartilage & 2 \\
Epiglottis & 4.5 \\
Mean tumor size (cm) & \\
Treatment & 11 \\
Surgery alone & 5 \\
Surgery and radiation & 2 \\
Radiation alone & 1 \\
Unknown & \\
Patient Outcome* & 11 patients \\
Alive, no evidence of disease (n) & $0.5-8 \mathrm{y}$ \\
Survival (range) & $4.2 \mathrm{y}$ \\
Survival (mean) &
\end{tabular}

*Available for only 11 patients.

patients were from civilian sources, including university medical centers and foreign contributors.

Materials within the institute's files were supplemented by a review of the patient demographics (gender, age, and ethnicity); symptoms at presentation (including duration); and medical history (specifically, a history of previous radiation exposure or tobacco and/or alcohol use). In addition, we reviewed surgical pathology and operative reports and obtained follow-up information from oncology data services by written questionnaires or by direct communication with the treating physician or the patient. Follow-up data included exact tumor location, tumor size, treatment modalities, and current patient and disease status. Patient 7 has been previously reported (5). This clinical investigation was conducted in accordance and compliance with all statutes, directives, and guidelines of the Code of Federal Regulations Title 45, Part 46, and the Department of Defense Directive 3216.2 relating to human subjects in research.

Radiographic studies were available and were reviewed in 3 cases (Cases 1, 3, and 4). Hematoxylin and eosin-stained slides from all patients were reviewed for the morphologic features of GCT. A number of histologic observations were recorded for each tumor as follows: tumor periphery (circumscribed versus infiltrative); growth pattern; nuclear pleomorphism (determined by an increased nuclear to cytoplasmic ratio, nuclear contour irregularities, irregular nuclear chromatin distribution, and prominent or poilkilonucleoli); presence and type of giant cells identified; mitotic index (number of mitotic figures per 10 high-power fields (HPFs) using a $10 \times$ objective and $40 \times$ lens on a BX40 Olympus microscope); presence or absence of atypical mitotic figures (defined by abnormal chromosome spread, tripolar or quadripolar forms, circular forms, or as indescribably bizarre); cyst formation; hemorrhage; the presence and degree of tumor necrosis (defined as areas of cell death, not associated with areas of degeneration); presence of bone or cartilage formation; presence of inflammatory cells; and presence of acellular bands of fibrosis.

We specifically excluded cases in which the tumor was thought to arise externally to the laryngeal cartilages (such as the vertebral column) or to be invading into the larynx.

Our review of the literature was based on a MEDLINE search from 1966 to 2000 with a few specific earlier articles included for balance and background (Table 1). Translations of foreign literature were obtained to the best of our ability.

\section{RESULTS}

\section{Sociodemographic Characteristics}

The patients included six men and two women, aged 26 to 62 years (mean age at presentation, 44.5 years; Table 2). The female patients presented at an average age of 57.5 years, older than the male patients (40.2 years). Five patients were Caucasian, and the ethnicity of the remaining three patients was unknown. The patients presented clinically with a palpable neck mass ( $n=5$ patients), hoarseness ( $n=3$ patients), airway obstruction ( $n=3$ patients), and dysphagia ( $n=2$ patients). Patients

TABLE 2. Clinical Features of Eight Giant Cell Tumors of the Larynx

\begin{tabular}{|c|c|c|c|}
\hline No. & Age/Gender & Clinical Presentation (Duration of Symptoms in Mo) & Location \\
\hline 1 & $44 / \mathrm{M}$ & Hoarseness; palpable left neck mass & Hyoid bone extending to involve thyroid cartilage \\
\hline 2 & $57 / \mathrm{M}$ & Dysphagia; airway obstruction & $\begin{array}{l}\text { Cricothyroid cartilage, bilateral left }>\text { right, } \\
\text { posterior, involves trachea and esophagus }\end{array}$ \\
\hline 3 & $37 / \mathrm{M}$ & Sore throat; anterior neck mass (9) & Cricothyroid cartilage, right \\
\hline 4 & $40 / \mathrm{M}$ & Laryngeal obstruction & Thyroid cartilage \\
\hline 5 & $53 / \mathrm{F}$ & $\begin{array}{l}\text { Progressive respiratory distress; near total occlusion } \\
\text { of larynx }\end{array}$ & $\begin{array}{l}\text { Thyroid cartilage and anterior commissure, } \\
\text { invading trachea }\end{array}$ \\
\hline 6 & $62 / \mathrm{F}$ & Hoarseness; neck mass & Thyroid cartilage, left \\
\hline 7 & $26 / \mathrm{M}$ & Hoarseness; neck mass; dysphagia (6) & Thyroid cartilage, pyriform sinus extension (right) \\
\hline 8 & $37 / \mathrm{M}$ & Hoarseness; neck swelling; voice loss (7) & Thyroid cartilage, pyriform sinus extension (left) \\
\hline
\end{tabular}

M, male; F, female. 
also complained of a sore throat, chronic sinus infection, voice loss, and ear pain. The duration of symptoms ranged from 1 to 9 months (mean, 7.3 months). In general, the neck mass was considered to be "slow growing," with the hoarseness, airway obstruction, or dysphagia bringing the patient to seek clinical intervention. A tobacco history or history of heavy alcohol use was not elicited from any patients. Similarly, no patients had prior radiation exposure.

\section{Radiographic Findings}

Plain X-rays, computed tomography (CT) scans, and magnetic resonance images (MRI) were obtained in three patients. These studies reviewed a homogeneous mass arising from the cartilages, often with areas of calcification or bone formation. It appears that these tumors were exploding the cartilages from within, destroying the cartilage and thinning the periphery, extending into the soft tissues of the larynx and into the endolaryngeal spaces.

\section{Pathology \\ Macroscopic Features}

The tumors arise in sites of ossification of the thyroid ( $n=6$ tumors) and cricoid ( $n=2$ tumors) cartilage with an expansile, infiltrative growth pattern into the surrounding soft tissues. The masses were centered within the cartilage (thyroid or cricoid), with the cartilaginous tissue replaced by a destructive tumor. The tumors were described as supraglottic $(n=3)$ or transglottic $(n=3)$, with a specific location not given for two tumors. The tumors ranged in size from 2.4 to $7 \mathrm{~cm}$, with a mean size of the tumors of $4.2 \mathrm{~cm}$. The largest tumor was from a 37-year-old male patient, treated by laryngectomy, chemotherapy, and radiation therapy. The patient was dead without evidence of disease 19.4 years later. On cut section, the tumors were broadly infiltrative into the cartilage and soft tissue with cartilage destruction. The tumors were soft, with areas of hemorrhage ( $n=5$ tumors) and cystic degeneration ( $n=3$ tumors).

\section{Microscopic Features}

All tumors were submucosal and showed no connection to the surface epithelium, and there was no surface ulceration (Fig. 1). All lesions demonstrated the typical histologic features of GCTs of skeletal bone. There were fibroblasts, histiocytes, and innumerable multinucleated osteoclast-like giant cells (Figs. 1-4). The giant cells were found dispersed throughout the tumor, without any areas of aggregation. The giant cells contained a variable number of nuclei, occasionally in excess of 20 nuclei per cell

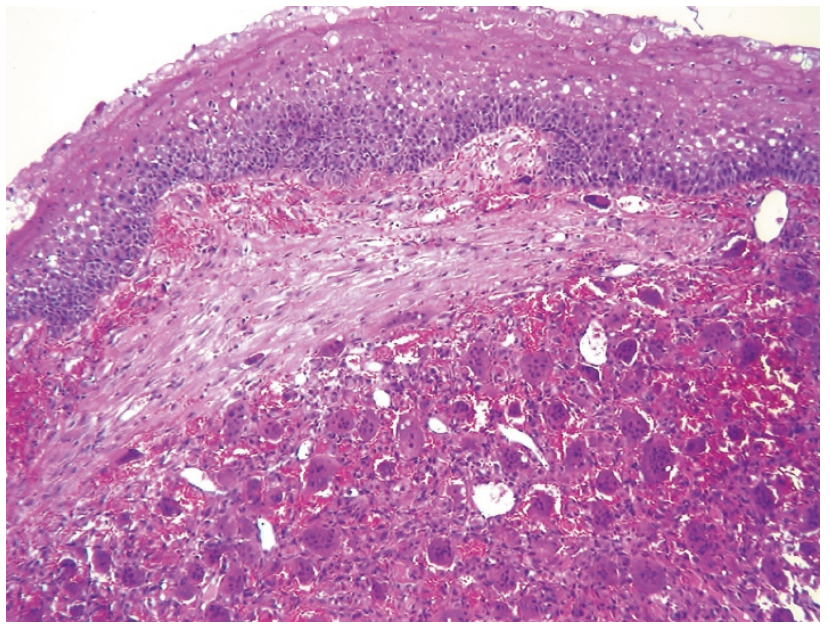

FIGURE 1. Low-power photomicrograph of a submucosal polypoid nodule without any surface involvement or point of origin.

(Figs. 3-4). The giant cells were lying in a bed of stromal spindle cells, the nuclei of which were identical histologically to those found in the giant cells (Fig. 4). The entire proliferation was separated into small groups by a delicate, complex, and arborizing vascular plexus. Mitotic figures were easily identified, although not increased in number. There were, on average, 4 mitotic figures per $10 \mathrm{HPFs}$ (Fig. 3 , inset), although there was a range of 1 to 12 mitoses per 10 HPFs. No atypical mitotic figures were identified. Extravasated erythrocytes, hemosiderin-laden macrophages, areas of hemorrhage $(n=5)$, and cystic degeneration $(n=3)$ were all noted (Fig. 2). Bone formation in terms of endochondral ossification was present in 5 cases, with true bone present within these tumors (Fig. 2). Histiocytes and inflammatory cells were present but were not conspicuous nor seen as a "response" to the tumor.

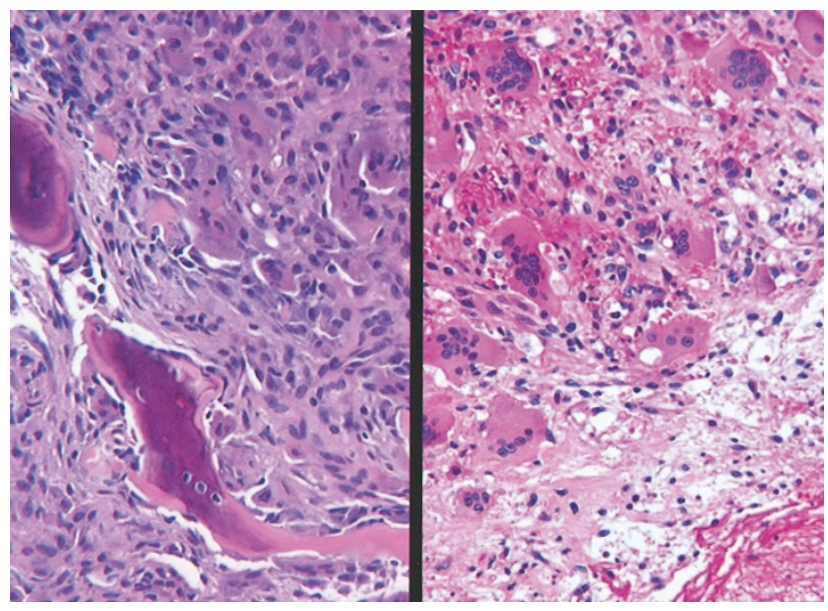

FIGURE 2. An intermediate power demonstrates reactive bone formation (left) and areas of cystic degeneration (lower right). 


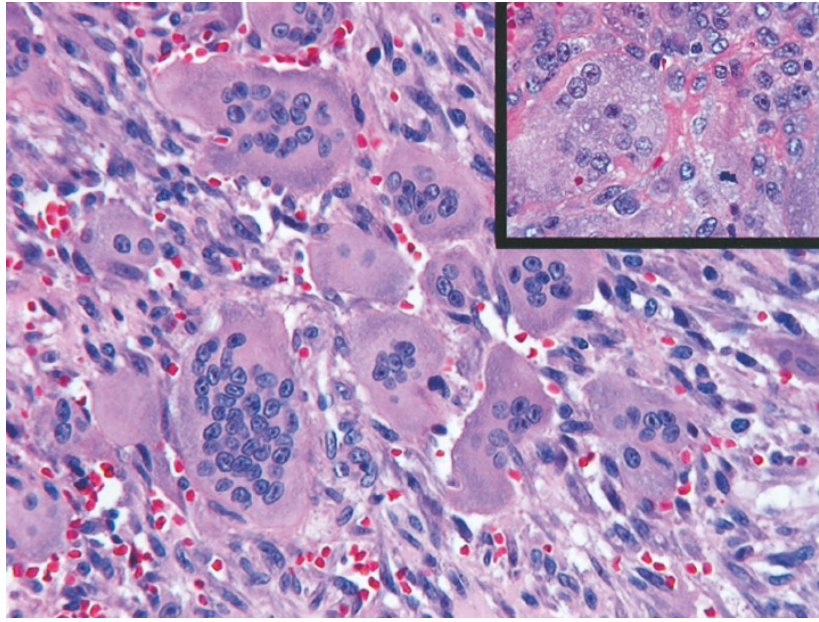

FIGURE 3. An intermediate power demonstrates the cellular mononuclear stromal component with a sprinkling of giant cells throughout, whereas the inset demonstrates a typical mitotic figure.

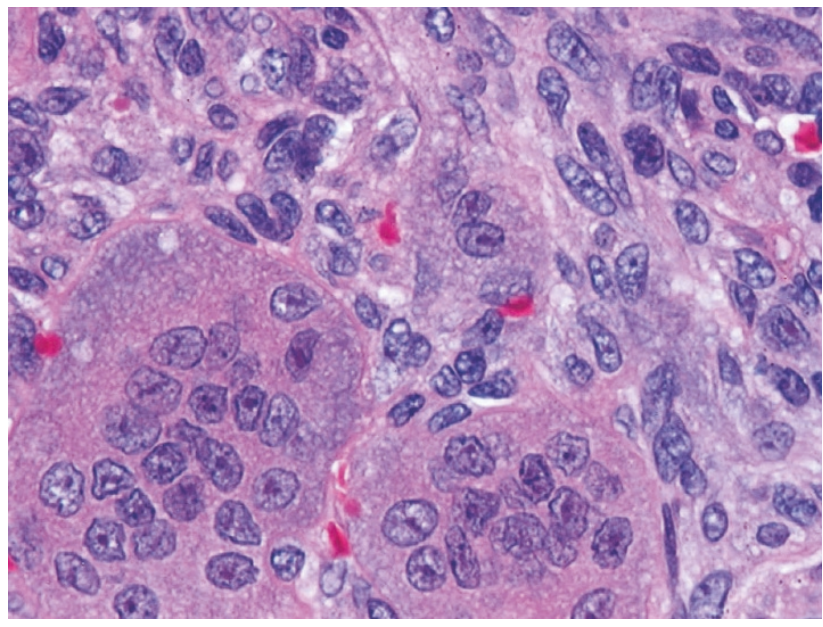

FIGURE 4. A high-power view illustrates osteoclast-type giant cells with nuclei similar to those of the stromal component.

\section{Treatment and Patient Outcome}

One foreign patient was lost to follow-up, but adequate follow-up was available in 7 patients. Patients were treated with surgery, radiation, and/or chemotherapy as follows: biopsy only with radiation therapy ( $n=1$ patient); biopsy followed by radiation therapy and chemotherapy and then total laryngectomy ( $n=1$ patient); wide local resection
( $n=3$ patients); partial laryngectomy ( $n=1$ patient); or total laryngectomy ( $n=2$ patients; Table $3)$. Because of the large deformity frequently associated with the removal of the tumor, significant changes in phonation were a known result of the surgery.

As a group, the overall patient survival was excellent, with a mean follow-up period of 11.3 years and a range of 0.5 to 24.0 years. Five patients were alive at last follow-up without evidence of disease (mean follow-up, 6.9 years), and two patients had died of unrelated causes without evidence of disease (mean survival, 22.2 years). There was no difference in outcome based on the gender, age, anatomic site of involvement, size of the tumor, or histologic features. No patient developed a recurrence of disease nor displayed evidence of morbidity from tumors during the follow-up period.

\section{DISCUSSION}

Giant cell tumor accounts for about 5\% of all biopsied primary bone tumors and about $20 \%$ of benign bone tumors (26-28). Approximately $2 \%$ of all GCTs arise in the head and neck region, with the majority of them occurring in the sphenoid, ethmoid, or temporal bones (29-32). Giant cell tumors arising primarily in the larynx are quite rare, with only individual case reports in the literature $(n=20$ cases; 1-20). Giant cell tumors of the long bones almost always affect the mature skeleton (closed epiphyseal plates). Approximately 10 to $15 \%$ of patients with GCT are younger than 20 years, with less than $2 \%$ of tumors adjacent to an open epiphysis. The peak incidence in long bones is in the 3rd decade of life, with a gradual decrease into late adulthood (30), younger than the average 44.5 years in this series and than the 42 years for the cases reported in the literature for laryngeal GCTs. In the long bones, GCTs are one of the few osseous neoplasms showing a female predilection $(1.3: 1 ; 30)$, in sharp contrast to this series and to the patients reported in the literature, for whom 25 of the 28 patients have been men (M:F = 10:1).

GCTL are benign neoplasms that can cause significant morbidity in the larynx because of size and

TABLE 3. Treatment and Clinical Outcome of Eight Giant Cell Tumors of the Larynx

\begin{tabular}{|c|c|c|c|c|}
\hline No. & Initial Therapy & Additional Therapy & Tumor Recurrence & Patient status (follow-up in y) \\
\hline 1 & Supraglottic laryngectomy & None & No & A, NED (0.6) \\
\hline 2 & Biopsy & External beam radiation & No & A, NED (1.6) \\
\hline 3 & Wide local resection & None & No & A, NED (13.9) \\
\hline 4 & Wide local resection & None & Unknown & Lost to follow-up \\
\hline 5 & Wide local resection & None & No & A, NED (16.9) \\
\hline 6 & Total laryngectomy & None & No & D, NED (24.9) \\
\hline 7 & Total laryngectomy & None & No & A, NED (1.5) \\
\hline 8 & Biopsy only & Radiation and cytoxan & No & D, NED (19.4) \\
\hline
\end{tabular}

A, NED, alive, no evidence of disease; D, NED, dead, no evidence of disease. 
invasion into vital structures. Airway obstruction may be significant, requiring urgent surgical intervention. Clinically, GCTL may simulate a malignant neoplasm because of the large tumor size and rapid growth, but accurate biopsy interpretation will remove malignant entities from consideration. The goal of surgical resection should be complete local control. Although there are not sufficient numbers in this clinical series to accurately predict future biologic behavior of these lesions, GCTL seem to behave less aggressively than their long bone counterparts because none of our patients developed a recurrence or metastatic disease. Radiation therapy and/or chemotherapy is not a necessary adjunct in the treatment of these laryngeal tumors.

The patients in this series had an excellent longterm prognosis. However, given the overall mean size of the tumors, it was impossible to retain laryngeal preservation without sacrificing complete surgical removal of the tumor. Therefore, patients who had partial or complete laryngectomy did have the associated morbidity of reduced voice quality, a consequence that must be taken into consideration when treating these tumors. No patients died of causes related to the tumor, nor have any developed recurrences or distant metastases. Therefore, local control without adjuvant therapy will yield an excellent long-term patient outcome, based on the results of this clinical study.

As in the long bones, these tumors contain a prominent giant cell component requiring careful clinicoradiologic correlation and microscopic evaluation of the mononuclear component to exclude other entities. A true GCT of bone should contain a large number of giant cells in a diffuse distribution (26). However, although the presence of giant cells can suggest a GCT, the diagnosis is made by a combination of the giant cells and the mononuclear cells of the stroma (31). These mononuclear cells are predominantly round, oval, or polygonal in shape and can resemble normal histiocytes $(26,29)$. The nuclei of the stromal cells are indistinguishable and very closely resemble those within the multinucleated giant cells, a feature that can be helpful in separating this entity from other lesions in the differential diagnosis. Mitotic figures in the mononuclear cells may be abundant, especially in females with increased endogenous or exogenous hormone levels in the skeletal GCTs (26), although we did not note a particular increase in mitotic figures in the female patients in this series (both of whom were postmenopausal). Mitotic figures were usually identified, with a mean of 4 per $10 \mathrm{HPF}$ (3 per 10 HPF in women and 4 per 10 HPF in men).

The stroma of most GCTs is vascular and contains numerous, thin-walled capillaries, often with small areas of hemorrhage (11). In addition, a large percentage of tumors also contain secondary de- generation as evidenced by the formation of cysts. These findings were duplicated in the GCTs of the larynx, both in this series and in the cases reported in the literature.

In our clinical series, all of the lesions involved the thyroid cartilage, with evidence of extension into the adjacent structures. GCTL arise in the supporting cartilages of the larynx, specifically in association with areas of endochondral ossification as part of the aging process of the laryngeal cartilages. Not only did we note the presence of bone within the cartilage proper in all cases examined, but reactive, nonneoplastic osteoid matrix deposition was also noted in a number of cases $(n=6)$. Cytologic atypia was absent, thereby excluding the possibility of a malignant bone-forming tumor. It is with interest that we note that the tumors occurred in the cartilages of the larynx that had undergone secondary ossification and so were actually occurring within the "bones" of the larynx, mimicking their counterparts in the long bones. We do not really have an explanation for this because there is no true epiphyseal structure in the laryngeal cartilages.

The differential diagnosis includes a host of entities, including, although not limited to, giant cell reparative granuloma, brown tumor of hyperparathyroidism, osteoblastoma, chondroblastoma, aneurysmal bone cyst, nonossifying fibroma, foreign body reaction, benign fibrous histiocytoma, osteosarcoma with abundant giant cells, and carcinoma (including spindle cell or sarcomatoid carcinoma) with giant cells. These lesions can be difficult to distinguish from one another, especially on fine needle aspiration or frozen section, necessitating careful and thorough clinicopathologic correlation (19). It is patently obvious, but should be stressed nevertheless, that recognition of these lesions as benign tumors may save the patient from unnecessary radical surgery and adjuvant therapy $(27,28$, 33).

Giant cell reparative granuloma and brown tumor of hyperparathyroidism are histologically similar to one another but differ from giant cell tumor $(11,12,31)$. A clear-cut distinction is not always possible, but in general, giant cell tumor contains a more uniform distribution of larger giant cells with many more nuclei per cell (31). In giant cell reparative granuloma, the giant cells tend to be aggregated, often around areas of hemorrhage, and giant cells with more than 20 nuclei are uncommon. In contrast to giant cell tumors, giant cell reparative granulomas have a more fibrotic stroma with more prominent hemorrhage and hemosiderin deposition, as does the brown tumor of hyperparathyroidism (34).

Osteoblastoma will contain giant cells but in neither the quantity nor quality noted in giant cell 
tumor. An osteoblastoma has increased cellularity with haphazard proliferation of fibrovascular tissue and interlacing trabeculae of osteoid. Areas within osteoblastoma have rather broad sheets of mineralized osteoid with little intervening stroma, easily separated from giant cell tumor. Osteoclasts may also be numerous along the trabeculae in areas of resorption. Moreover, osteoblastoma typically has a prominent, although loose, fibrovascular tissue between the islands and trabeculae of bone, with prominent, dilated capillaries.

When giant cells are present in chondroblastoma, they are not nearly as numerous or uniform as those in a giant cell tumor. Chondroblastoma contains islands of cartilage amid a mononuclear cell background in which the mononuclear cells have a moderate amount of amphophilic cytoplasm and grooved, indented nuclei, distinct from those in giant cell tumor. The mononuclear cells may also have pericellular calcifications in a so-called chicken-wire pattern.

Giant cell tumor may be associated with secondary aneurysmal bone cyst formation but will usually contain large solid areas with the typical histologic appearance of giant cell tumor (11). The radiographic features of the two lesions may overlap and will not always allow radiographic distinction (35). The radiographic and clinical features of a nonossifying fibroma usually allow for an easy diagnosis, but if necessary, the histologic features of spindle stromal cells, fibrosis, and aggregates of foamy macrophages will allow for separation from GCTs. A foreign body giant cell reaction will contain giant cells but not a mononuclear cell stroma $(36,37)$.

The diagnosis of benign fibrous histiocytoma is usually one of exclusion. Giant cell tumors can have areas of storiform, cellular fibrous tissue intermixed with occasional multinucleated giant cells in a pattern similar to that of benign fibrous histiocytoma, but this pattern of growth usually does not predominate, and a benign fibrous histiocytoma is exceedingly uncommon in the larynx.

Osteosarcoma can occasionally have a histologic appearance similar to giant cell tumor, but the radiographic features (heavy mineralization in an invasive tumor) combined with the histologic features of delicate strands of osteoid around pleomorphic, atypical mononuclear cells, with necrosis and atypical mitotic figures, should make the diagnosis clear (38-40).

The multinucleated tumor giant cells of a carcinoma are usually remarkably atypical rather than containing the relatively bland "stromal-cell" nuclei of a giant cell tumor. If any question remains, the application of immunohistochemical studies to define the stromal cells and/or giant cells will help to make the distinction apparent (39-45).

\section{CONCLUSIONS}

GCTL are rare tumors, usually presenting in middle-aged male patients with obstructive symptoms. The tumors arise from the cartilages (thyroid most frequently) of the larynx in areas of endochondral ossification, with a typical histology of numerous giant cells containing many nuclei that are histologically indistinguishable from the nuclei of the stromal cells surrounding the giant cells. Degenerative changes, including cyst formation, are common, whereas mitotic figures are uncommon, and atypical mitotic figures are not seen. Complete but conservative surgical excision is the treatment of choice, with attempts to preserve the quality of the voice and speech if at all possible. Adjuvant therapy is unnecessary for these tumors. The patients enjoy an excellent long-term prognosis without the development of recurrences or metastatic disease.

\section{REFERENCES}

1. Badet JM, Chobaut JC, Kantelip B, Racle A. Tumeur a cellules geantes du cricoide. A propos d'un cas. Ann Otolaryngol Chir Cervicofac 1992;109:52-6.

2. Borghese M, Porcaro C, Leone CA. Su di un raro caso di tumore a mielopassi della laringe. Otorinolaringol Ital 1988; 38:157-9.

3. Federova SS. Giant cell tumor of the larynx. Vestn Otorinolaringol 1951;4:80-1.

4. Goto TY, Nakashima Y. Giant cell tumor of the larynx. Otol Fukuoka 1973;19:507-9.

5. Hall-Jones J. Giant cell tumour of the larynx. J Laryngol Otol 1972;86:371-81.

6. Hinni ML. Giant cell tumor of the larynx. Ann Otol Rhinol Laryngol 2000;109:63-6.

7. Kaliteevskii PF, Korol'kova IA. Nabliudenie lokalizatsii osteroblastoklastomy v gortani. Vestn Otorinolaringol 1966;28: 69-71.

8. Kohn K. Kehlkopf und luftrohre. In: Doerr W, Seifert G, Uehlinger E., editors. Spezielee pathologische anatomie. Berlin: Springer; 1969: 226-8.

9. Kotarba E, Niezabitowski A. Guz olbrzymiokomorkowy tkanek miekkich krtani. Otolaryngol Pol 1974;28:331-5.

10. Kubo R, Katsuda K, Nobori T. Riesenzellentumor des kehlkopfes. Otol Fukuoka 1976;22:776-9.

11. Martin PC, Hoda SA, Pigman HT, Pulitzer DR. Giant cell tumor of the larynx. Case report and review of the literature. Arch Pathol Lab Med 1994;118:834-7.

12. Murrell GL, Lantz HJ. Giant cell tumor of the larynx. Ear Nose Throat J 1993;72:360-1.

13. Perrino A. Tumore a cellule giganti della laringe. Ann Laringol (Torino) 1958;57:140-9.

14. Pohl W. Uber ein Riesenzellgewachs des kehlkopfes. Z Laryngol Rhinol Otol 1968;47:727-9.

15. Ribari O, Elemr G, Balint A. Laryngeal giant cell tumour. J Laryngol Otol 1975;89:857-61.

16. Rudert H. Riesenzelltumor des kehlkopfes. HNO 1971;19: 306-9.

17. Tsybyrne GA, Bogdanskaia NI. Osteoblastoklastoma gortani (odno nablinderie). Vopr Onkol 1979;25:62-4.

18. Wagemann W. Riesenzellgeschwulst in kehlkopfraum. HNO 1952;3:92-3. 
19. Werner JA, Harms D, Beigel A. Giant cell tumor of the larynx: case report and review of the literature. Head Neck 1997;19: 153-7.

20. Wessely E. Ein Fall von Epulis laryngis. Monatsschr Ohrenheilkd 1940;74:158-61.

21. Cady B, Rippey JH, Frazell EL. Non-epidermoid cancer of the larynx. Ann Surg 1968;167:116-20.

22. Clerf LH. Sarcoma of the larynx. Report of eight cases. Arch Otolaryngol 1946;44:517-24.

23. Ferlito A. Histological classification of larynx and hypopharynx cancers and their clinical implications. Pathologic aspects of 2052 malignant neoplasms diagnosed at the ORL Department of Padua University from 1966 to 1976. Acta Otolaryngol Suppl 1976;342:1-88.

24. Harwood A. Cancer of the larynx. The Toronto experience. J Otolaryngol Suppl 1982;11:3-21.

25. Hyams VJ, Batsakis JG, Michaels L. Tumors of the upper respiratory tract and ear. Washington, DC: Armed Forces Institute of Pathology; 1988. p. 76-81.

26. Dahlin DC, Cupps RE, Johnson EWJ. Giant-cell tumor: a study of 195 cases. Cancer 1970;25:1061-70.

27. Marcove RC, Lyden JP, Huvos AG, Bullough PB. Proceedings. Giant cell tumors treated by cryosurgery: an analysis of 25 cases. Proc Natl Cancer Conf 1972;7:951-7.

28. Marcove RC, Lyden JP, Huvos AG, Bullough PB. Giant-cell tumors treated by cryosurgery. A report of twenty-five cases. J Bone Joint Surg Am 1973;55:1633-44.

29. Pitkethly DT, Kempe LG. Giant cell tumors of the sphenoid. Report of two cases. J Neurosurg 1969;30:301-4.

30. Geissinger JD, Siqueira EB, Ross ER. Giant cell tumors of the sphenoid bone. J Neurosurg 1970;32:665-70.

31. Hamlin WB, Lund PK. "Giant cell tumors" of the mandible and facial bones. Arch Otolaryngol 1967;86:658-65.

32. Stevens WW, Weaver EN. Giant cell tumors and aneurysmal bone cysts of the spine: report of four cases. South Med J 1970;63:218-21.
33. Devaney KO, Ferlito A, Rinaldo A. Giant cell tumor of the larynx. Annu Otol Rhinol Laryngol 1998;107:729-32.

34. Carlotti AE, Camitta FD, Connor TB. Primary hyperparathyroidism with giant cell tumors of the maxilla: report of case. J Oral Surg 1969;27:722-7.

35. Shadaba A, Zaidi S. Aneurysmal bone cyst of the hyoid. J Laryngol Otol 1992;106:71-2.

36. Stephens CB, Arnold GE, Stone JW. Larynx injected with polytef paste. Arch Otolaryngol 1976;102:432-5.

37. Varvares MA, Montgomery WW, Hillman RE. Teflon granuloma of the larynx: etiology, pathophysiology, and management. Annu Otol Rhinol Laryngol 1995;104:511-5.

38. Kuwabara H, Saito K, Shibanushi T, Kawahara T. Malignant fibrous histiocytoma of the larynx. Eur Arch Otorhinolaryngol 1994;251:178-82.

39. Ferlito A, Friedmann J, Recher G. Primary giant cell carcinoma of the larynx. A clinico-pathological study of four cases. ORL J Otorhinolaryngol Relat Spec 1985;47:105-12.

40. Ferlito A, Nicolai P, Recher G, Narne S. Primary laryngeal malignant fibrous histiocytoma: review of the literature and report of seven cases. Laryngoscope 1983;93:1351-8.

41. Ferlito A. Primary anaplastic giant cell adenocarcinoma of the larynx. J Laryngol Otol 1976;90:1053-60.

42. Alguacil-Garcia A, Alonso A, Pettigrew NM. Sarcomatoid carcinoma (so-called pseudosarcoma) of the larynx simulating malignant giant cell tumor of soft parts. A case report. Am J Clin Pathol 1984;82:340-3.

43. Batsakis JG, Suarez P. Sarcomatoid carcinomas of the upper aerodigestive tracts. Ad Anat Pathol 2000;7:282-93.

44. Hyams VJ. Spindle cell carcinoma of the larynx. Can J Otolaryngol 1975;4:307-13.

45. Leventon GS, Evans HL. Sarcomatoid squamous cell carcinoma of the mucous membranes of the head and neck: a clinicopathologic study of 20 cases. Cancer 1981;48:9941003. 